\title{
Polityka ex cathedra. Naukowcy jako kandydaci w wyborach w 2019 roku
}

\author{
The Politics ex cathedra. \\ Scientists as Candidates in Elections in 2019
}

Stowa kluczowe: wybory, komitety wyborcze, kandydaci, naukowcy

Keywords: elections, electoral committees, candidates, scientists

Abstrakt: Przedmiotem artykułu jest analiza obecności naukowców na listach wyborczych zarejestrowanych przez relewantne komitety wyborcze w wyborach do Parlamentu Europejskiegoiparlamentunarodowegow Polscew2019 roku. Autorskoncentrował się na odpowiedzi na pytania dotyczące liczby naukowców na listach wyborczych i zróżnicowaniu reprezentacji naukowców na listach komitetów lewicowych, centrowych i prawicowych. Efektem analizy sq wnioski ukazujące zróżnicowanie list wyborczych w wyborach do Parlamentu Europejskiego i Senatu oraz Sejmu.

Abstract: An object of the article is the analysis of the presence of scientists on tickets registered by relevant electoral committees in elections to European Parliament and national Parliament in Poland in 2019. The author concentrated on the answer on questions concerning numbers of scientists on lists of candidates and to the differentiation of the representation of research workers on tickets of left-wing, right-wing and centrist committees. An effect of the analysis are conclusions showing differentiation of electoral registers in elections to European Parliament and the Senate and Seym.

* ORCID ID: https://orcid.org/0000-0003-2097-1456, doktor habilitowany, profesor Uniwersytetu Wrocławskiego, kierownik Zakładu Badania Aktywności Politycznej i Społecznej, Instytut Politologi Uniwersytet Wrocławski.Email: dariusz.skrzypinski@uwr.edu.pl. 


\section{Wprowadzenie}

18 października 2019 roku, kilka dni po wyborach parlamentarnych jeden z liderów „Solidarnej Polski”, europoseł P.Jaki napisał na Facebooku „Musimy sobie odpowiedzieć na pytanie, dlaczego mimo obiektywnych sukcesów [...] słabości i śmieszności KO - dalej większość osób wybiera partie opozycyjne? A wzmocniona lewica wraca do Sejmu. Moim zdaniem między innymi dlatego, że nie sięgamy do zmiany fundamentów III RP, dlatego że na naszych oczach trwa proces wrogiej indoktrynacji i socjalizacji społeczeństwa - zamiany flagi biało-czerwonej na „tęczową”, społeczeństwa wolnościowo-konserwatywnego na lewackie. Świat wartości społeczeństwa w większości kształtują media liberalno-lewicowe oraz lewicowe uniwersytety. I smutną puentą tego procesu było oświadczenie rektorów polskich uczelni, że trzeba karać za krytykę ideologii LGBT"1. Zainaugurował tym samym dyskusję nad ideologicznym obliczem polskich uczelni wyższych i ich wpływem na postawy i zachowania polityczne Polaków. Sam temat nie przyciągnął szczególnej uwagi opinii publicznej i szybko został wyparty przez inne wątki, jednak głos polityka Zjednoczonej Prawicy i wspierających go publicystów, m.in. braci Karnowskich, ukazał, że kwestia politycznych sympatii naukowców budzi zainteresowanie.

Trudno odpowiedzieć, czy inicjatorzy wspomnianej dyskusji mieli świadomość, że rok wcześniej ukazał się raport, przedstawiający wyniki badań nad poglądami politycznymi, społecznymi, obyczajowymi, środowiskowymi i gospodarczymi polskich naukowców. Jego autorzy M. Misiak i Ł. Sakowski pokazali w nim, że statystyczny polski naukowiec jest znacznie bardziej liberalny niż statystyczny Polak (72\% do 53,4\% respondentów). Warto także odnotować, ze według autorów badań, wspomniane wyżej poglądy w największym stopniu są obecne wśród przedstawicieli nauk przyrodniczych, społecznych oraz medycznych i nauk o zdrowiu, w najmniejszym natomiast w gronie reprezentantów nauk technicznych, rolnych i ścisłych ${ }^{2}$.

W gronie naukowców dostrzegli oni także wyższy poziom akceptacji w obszarze polityki społeczno-gospodarczej dla rozwiązań bliskich socjalizmowi, w ramach, których „społeczeństwo powinno mieć pewną kontrolę nad dystrybucją dóbr (np. poprzez rząd lub organizacje pozarzą-

1 https://www.facebook.com/PatrykJaki/posts/2208373619266703?_tn_=K-R(29.12.2019).

2 Raport. Poglądy polityczne, społeczne, obyczajowe, środowiskowe i gospodarcze wśród polskich naukowców w 2018 roku, s. 10-11. 
dowe) oraz powinno rozdzielać te dobra sprawiedliwie pośród członków społeczeństwa" (26,8\% do 13,4\% badanych). Taka postawa była szczególnie widoczna $\mathrm{w}$ gronie respondentów reprezentujących nauki społeczne i humanistyczne, w najmniejszym natomiast wśród badaczy z dziedzin nauk rolnych i technicznych ${ }^{3}$.

Przywołana dyskusja i interesujący raport z badań skłoniły mnie do podjęcia innego tematu, w istotny sposób odwołującego się do kwestii podjętych przez wspomnianych polityków i badaczy. Problemem, na którym postanowiłem się skoncentrować, jest kwestia zaangażowania politycznego polskich naukowców, postrzeganego przez pryzmat ich udziału, jako kandydatów w wyborach, jakie przeprowadzono w Polsce w 2019 roku$^{4}$. Samo zaangażowanie rozumiem za K. Skarżyńską, jako formę uczestnictwa politycznego, popartego także określoną postawą poznawczo-emocjonalną obejmującą miedzy innymi zainteresowanie polityką, wiedzę o niej, znajomość instytucji i reguł jej uprawiania oraz posiadanie skrystalizowanych poglądów ${ }^{5}$. Cechy te jak sądzę, charakteryzują interesującą mnie grupę zawodową niejako ex definione, a wynikają ze szczególnego katalogu ról społecznych przez nią pełnionych. Nie przypadkiem wśród cech, które powinny cechować nauczyciela akademickiego, a stanowią oni zdecydowaną większość badanej grupy wskazuje się: „otwartość na otaczający świat i ciekawość świata; innowacyjność, polegającą na umiejętności przystosowania do nowej sytuacji każdego rozwiązania, produktu czy pomysłu; odwagę w myśleniu i działaniu; aktywność społeczną oraz szeroką wiedzę i umiejętność jej stosowania"6.

W ramach realizowanego projektu podmiotem badania są relewantne komitety wyborcze ${ }^{7}$ startujące w wyborach do Parlamentu Europejskiego i wyborach parlamentarnych, które odbyły się w Polsce w 2019 roku. Przedmiotem badania jest skład list wyborczych zarejestrowanych

${ }^{3}$ Tamże, s. $12-13$.

${ }^{4} \mathrm{Na}$ temat procesu mianowania kandydatów wyborach zob. D. Skrzypiński, Proces mianowania kandydatów w wyborach prezydenckich jako mechanizm rozstrzygania dylematów strategicznych, «Studia Politologiczne» 2011, vol. 19.

${ }^{5}$ K. Skarżyńska, Człowiek a polityka. Zarys psychologii politycznej, Warszawa 2005, s. 157.

${ }^{6}$ A. Dziedziczak-Foltyn, Nauczyciele akademiccy jako prekursorzy imoderatorzy społeczeństwa wiedzy, «Nauka i Szkolnictwo Wyższe» 2006, nr 2/28, s. 66.

7 Ze względu na uzyskany wynik wyborczy (ponad 1\% głosów) i liczbę zarejestrowanych list, za komitety wyborcze spełniające ten warunek, uznałem w przypadku eurowyborów: PiS, Koalicję Europejską, Wiosnę, Konfederację, Lewicę Razem, Kukiz'15, a w przypadku wyborów parlamentarnych PiS, Koalicję Obywatelską, SLD, PSL, Konfederację. 
przez ww. komitety, ze szczególnym uwzględnieniem list w wyborach do Parlamentu Europejskiego i Sejmu. Ze względu na specyfikę podmiotowej struktury rywalizacji w wyborach do Senatu, w ramach której największe ugrupowania opozycyjne zawarły porozumienie, skutkujące ograniczeniem liczby kandydatów, analiza obecności naukowców na listach kandydatów do izby drugiej polskiego parlamentu pełni w moim tekście rolę pomocniczą. Jako naukowców w moich badaniach definiuję kandydatów, którzy w rubryce zawód na liście wyborczej dostępnej na stronie internetowej Państwowej Komisji Wyborczej8 wskazali: nauczyciel akademicki, wykładowca, naukowiec, pracownik naukowy. Natomiast dziedzinę, w ramach której prowadzą swoją aktywność naukową, a którą definiowałem na podstawie Rozporządzenia ministra nauki i szkolnictwa wyższego z dnia 20 września 2018 r. w sprawie dziedzin nauki i dyscyplin naukowych oraz dyscyplin artystycznych ${ }^{9}$, wskazywałem na podstawie informacji z listy wyborczej lub na podstawie danych zawartych w bazie ludzie nauki ${ }^{10}$, ewentualnie na profilach internetowych kandydatów ${ }^{11}$.

Odwołując się do przywołanych badań M. Misiaka i Ł. Sakowskiego sformułowałem trzy hipotezy badawcze:

H 1 Odsetek naukowców kandydujących z list wyborczych relewantnych komitetów wyborczych związanych ze środowiskiem wielkomiejskim (PiS, KE, KO, Wiosna, SLD, Lewica Razem) jest porównywalny, co oznacza, że odchylenie od maksimum jest nie większe niż $25 \%$.

H 2 Reprezentanci nauk społecznych i humanistycznych częściej startowali zlist komitetów o profilu liberalnym i lewicowym (KE, KO, Wiosna, SLD, Lewica Razem).

H 3 Reprezentanci nauk ścisłych, technicznych i rolnych częściej startowali z list komitetów o profilu konserwatywnym i narodowym (PiS, Konfederacja, Kukiz'15).

W celu weryfikacji wspomnianych wyżej hipotez zastosowałem przede wszystkim ilościową analizę list wyborczych ${ }^{12}$ relewantnych komitetów wyborczych z uwzględnieniem obecności na nich kandydatów spełniających ww. kryteria, pozwalające uznać ich za naukowców, prowadzących

\footnotetext{
8 https://pkw.gov.pl (20.01.2020).

${ }^{9}$ Dz. U. 25.09.2018, poz. 1818.

10 https://nauka-polska.pl/\#/home/search?_k=d93xe2 (20.01.2020).

11 https://www.wnp.pl (20.01.2020).

12 Łącznie przedmiotem analizy było 78 list zarejestrowanych w wyborach do Parlamentu Europejskiego, 224 listy zarejestrowane w wyborach do Sejmu oraz 279 kandydatów do Senatu.
} 
działalność badawczą lub dydaktyczno-badawczą w jednej z ośmiu dziedzin: Nauki Humanistyczne, Nauki Inżynieryjne i Techniczne, Nauki Medyczne i Nauki o Zdrowiu, Nauki Rolne i Leśne, Nauki Społeczne, Nauki Ścisłe i Przyrodnicze, Nauki o Sztuce, Nauki Teologiczne. Instrumentarium badawcze zastosowane $\mathrm{w}$ trakcie realizacji projektu zostało uzupełnione o analizę literatury i stron internetowych.

Zastosowane metody miały posłużyć do odpowiedzi na następujące pytania badawcze, pozwalające weryfikować założone hipotezy:

1. Ilu naukowców znalazło się na listach wyborczych zarejestrowanych przez badane komitety wyborcze?

2. Czy zauważalne były istotne różnice w odsetku kandydatów-naukowców obecnych na listach wyborczych zarejestrowanych przez badane komitety wyborcze?

3. Jaki był odsetek reprezentantów poszczególnych dziedzin nauki wśród kandydatów obecnych na listach wyborczych zarejestrowanych przez badane komitety wyborcze?

\section{Analiza zarejestrowanych list wyborczych}

Zanim przejdę do zasadniczej części mojego tekstu, pragnę odpowiedzieć na pytanie, jakie są motywacje politycznych liderów decydujących się na umieszczenie naukowców na listach wyborczych. Jak bowiem pokazuje praktyka życia politycznego w Europie zachodniej, badacze częściej są w niej obecni, jako eksperci czy doradcy ${ }^{13}$, a nie czynni politycy, choć oczywiście konsekwencją wyboru takiej roli są również liczne dylematy i wyzwania, z których część ma także polityczny charakter. Jeśli już podejmują się roli polityka, to czynią to stosunkowo rzadko (przykładem jest m.in. Angela Merkel, która karierę polityczną rozpoczęła, jako pracownik Centralnego Instytutu Chemii Fizycznej Akademii Nauk NRD), chętniej obejmują funkcje, które czynią z nich raczej „politycznie neutralnych” reprezentantów państwa, np.prezydenci Niemiec: Roman Herzog (prawnik z Uniwersytetu Monachijskiego i Wolnego Uniwersytetu w Berlinie) i Karl Carstens (prawnik i politolog z Uniwersytetu w Kolonii), niż uczestników politycznych sporów i partyjnej rywalizacji w parlamencie.

13 Zob. F.Znaniecki, Społeczne role uczonych, Warszawa 1984; T.Gundersen, Scientists as experts: A distinct role, «Studies in History and Philosophy of Science» 2018, nr 69; H. Hall, Scientists and Politicians, «Bulletin of Atomic Scientists» 1956, vol. 12, nr 2. 
Na fenomen ten zwrócił uwagę I. Boyd, podkreślając nikłą obecność naukowców w brytyjskiej Izbie Gmin ${ }^{14}$.

Jednak w analizowanych przypadkach odnajdujemy naukowców na listach wyborczych, a w konsekwencji wśród zdobywców mandatów jest ich więcej niż we wspomnianym wyżej parlamencie brytyjskim. Dlaczego tak się dzieje? Po pierwsze, przyczyna leży w odmiennych ścieżkach budowy kariery zawodowej naukowca i polityka w obu państwach. W takich przypadkach wybory dokonywane przez naukowców na jej początku i związane z tym wyzwania w modelu brytyjskim czy szerzej zachodnim trudniejszym czynią w przyszłości „zwrot ku polityce". Z pewnością niepoślednią w tym rolę odgrywają także warunki materialne, w jakich funkcjonują zachodni naukowcy. Nie bez wpływu na badany stan rzeczy może pozostawać także obawa naukowców-kandydatów o kondycję nauki i los instytucji, w których są sami zatrudnieni ${ }^{15}$. Z tej perspektywy możliwość współdecydowania (czasami oczywiście pozorna), jako parlamentarzysta o losach kolejnych refom nauki i szkolnictwa wyższego może być przejawem racjonalnejstrategii.

Po drugie, istotną rolę mogą odgrywać czynniki marketingowe, w ramach których polski wyborca oczekuje od kandydata pozytywnego dorobku życiowego. Jak pokazuje np. R. Alberski, dla wielu wyborców pozytywna ocena działalności kandydatów w przeszłości jest najważniejszym kryterium głosowania na nich ${ }^{16}$.

Z tej perspektywy warto uświadomić sobie, że Polacy tradycyjnie wśród wszystkich grup zawodowych najwyżej oceniają uczciwość i rzetelność naukowców ${ }^{17}$. Potwierdza to także ranking prestiżu zawodów, w którym naukowcy od lat cieszą się niezmiennie dobrą opinią u 82-84\% Polaków. Choć warto dodać, że w przeciągu ostatniego roku przestali być oni liderem tego rankingu, ustępując w ostatnim sondażu z jesieni 2019 roku strażakom, pielęgniarkom, wykwalifikowanym robotnikom i górnikom ${ }^{18}$.

Uwzględniwszy powyższy fakt, należy przywołać opinię M. Cichosz, która uważa, że wykształcenie i zawód jest jednym z istotniejszych kom-

${ }^{14}$ I. Boyd, Scientists and politics?, «Science» 2019, vol. 366, issue 6463, s. 281.

15 A. Żukiewicz, Społeczny ethos uczonych a procesy "zurzędniczania" nauki, «Rocznik Lubuski» 2018, t. 44, cz. 2, s. 81.

${ }^{16}$ R. Alberski, Wybrane czynniki wpływające na decyzje wyborców w elekcji parlamentarnej w 2011 roku, «Preferencje Polityczne» 2012, nr 3, s. 98.

17 Społeczne oceny uczciwości i rzetelności zawodowej, Komunikat z badań CBOS, 34/2016, Warszawa 2016, s. 4.

18 Które zawody poważamy?, Komunikat z badań CBOS, 157/2019, Warszawa 2019, s. 3-5. 
ponentów wizerunku kandydata ${ }^{19}$; kandydata, który w marketingu staje się istotnym elementem produktu politycznego oferowanego $\mathrm{w}$ trakcie kampanii, a który jest nierozłączny z oferentem, jakim jest partia i jej kandydaci właśnie ${ }^{20}$. Dlatego też biorąc pod uwagę społeczny wizerunek naukowców stają się oni atrakcyjnym „nośnikiem” politycznego programu. Tym bardziej, że nie można analizować obecności naukowców na listach wyborczych bez uwzględnienia koncepcji personalizacji polityki, która według M. Mazura „oznacza wzrost roli jednostek w polityce przy jednoczesnym ograniczeniu znaczenia partii, instytucji, kolektywnych tożsamości i problemów politycznych, po drugie określa wzrost roli atrybutów osoby polityka niezwiązanych bezpośrednio z polityką (związanych natomiast z osobą polityka) przy jednoczesnym ograniczeniu znaczenia atrybutów politycznych (istotnych dla odgrywania roli polityka)"21.

Jak zatem wyglądała obecność naukowców na listach wyborczych zarejestrowanych w wyborach, które odbyły się w Polsce w 2019 roku?

W wyborach do parlamentu Europejskiego badane komitety zarejestrowały łącznie 778 kandydatów, z czego 53, czyli 6,8\% to naukowcy. W tym gronie było 17 kobiet (32\%) oraz 36 mężczyzn (68\%). Interesujący może być fakt, że znaczące dysproporcje pomiędzy udziałem kobiet i mężczyzn występują na listach głównych graczy na scenie politycznej; PiS (20:80), Koalicji Europejskiej (30:70) i Wiosny (25:75). W przypadku pozostałych komitetów, możemy mówić o względnej równowadze pomiędzy kandydatami różnej płci. Warto jednak pamiętać, że o ile liczba kandydujących naukowców w przypadku wskazanych wyżej komitetów sięga od 12 do 15, to w przypadku Konfederacji, Lewicy Razem i Kukiz'15 wynosi od 3 do 5.

Rozkład kandydatów naukowców na listach poszczególnych komitetów ukazuje tabela 1. Jej lektura ukazuje nam, że odsetek naukowców na listach zarejestrowanych przez badane komitety wyborcze znacząco się różnił i wynosił od 2,3\% do 11,5\%. Daje się jednak dostrzec pewną prawidłowość, w ramach, której w przypadku komitetów, które uzyskały najlepszy wynik w wyborach, odsetek kandydujących naukowców, był faktycznie zbliżony i wynosił od 9,2\% do 11,5\%, czyli mieścił się w granicach założonego odchylenia.

${ }^{19}$ M. Cichosz, (Auto)kreacja wizerunku polityka na przykładzie wyborów prezydenckich w III RP, Toruń 2003, s. 63.

${ }^{20}$ K. Zajdowski, Marketing produktu politycznego. Analiza porównawcza, Warszawa 2017, s. 116.

21 M. Mazur, Polityka z twarzą. Personalizacja parlamentarnych kampanii wyborczych w Polsce w latach 1993-2011, Katowice 2014, s. 10. 
Tabela 1. Udział naukowców na listach wyborczych do Parlamentu Europejskiego

\begin{tabular}{|l|c|c|c|c|c|c|}
\hline \multicolumn{1}{|c|}{ Dziedzina Nauki/KW } & Konfederacja & Wiosna & KE & PiS & $\begin{array}{c}\text { Lewica } \\
\text { Razem }\end{array}$ & Kukiz'15 \\
\hline Humanistyczne (\%) & $1(20)$ & $4(33,3)$ & $2(15,4)$ & $7(46,6)$ & $3(60)$ & $2(66,6)$ \\
\hline Inżynieryjne i techniczne (\%) & - & - & $1(7,7)$ & $1(6,7)$ & $1(20)$ & - \\
\hline Medyczne i nauki o zdrowiu (\%) & - & $1(8,3)$ & - & - & - & - \\
\hline Rolne i Leśne (\%) & - & - & - & - & - \\
\hline Społeczne (\%) & $3(60)$ & $6(50)$ & $10(76,9)$ & $6(40)$ & $1(33,4)$ \\
\hline Ścisłe i przyrodnicze (\%) & $1(20)$ & $1(8,3)$ & - & $1(6,7)$ & $1(20)$ & - \\
\hline Sztuka (\%) & - & - & - & - & - \\
\hline Teologiczne (\%) & - & - & - & - & - \\
\hline $\begin{array}{l}\text { Razem (odsetek ogólnej liczby } \\
\text { kandydatów KW) }\end{array}$ & $5(3,8 \%)$ & $12(9,2 \%)$ & $13(10 \%)$ & $15(11,5 \%)$ & $5(3,8 \%)$ & $3(2,3 \%)$ \\
\hline $\begin{array}{l}\text { Mandaty zdobyte przez naukowców } \\
\text { (odsetek ogólnej liczby mandatów KW) }\end{array}$ & 0 & 0 & $6(27 \%)$ & $7(26,9 \%)$ & 0 \\
\hline
\end{tabular}

Źródło: opracowanie własne na podstawie danych z https://pkw.gov.pl (12.01.2020). 
Analizując natomiast udział reprezentantów poszczególnych dziedzin nauki na listach badanych komitetów wyborczych z perspektywy weryfikacji hipotez nr 2 i 3 musimy zauważyć, że nie znajdują one potwierdzenia. Reprezentantów nauk społecznych i humanistycznych, którzy skądinąd dominują na listach wyborczych, stanowiąc blisko 85\% badanej grupy, znajdujemy na listach komitetów zarówno centro-lewicowych, jak i prawicowych, gdzie stanowią najczęściej od 80 do 92\%. Od tego wyniku odbiegają jedynie listy zarejestrowane przez „Lewicę Razem”, choć być może jest to efekt zjednoczenia pod tym sztandarem niszowych ugrupowań lewicowych, których łączne poparcie w wyborach nieznacznie przekroczyło 1\%. Brak także znaczących różnic, jeśli chodzi o obecność na listach badanych komitetów reprezentantów nauk ścisłych, technicznych i rolnych.

W przypadku list badanych komitetów, które startowały w wyborach do Sejmu, to znalazło się na nich 113 naukowców, którzy stanowili około 2,5\% zarejestrowanych kandydatów spośród ogólnej liczby 4549. W tym gronie było 37 kobiet (32,7\%) i 76 mężczyzn (67,3\%). Na poszczególnych listach odsetek kobiet wahał się od ok. 21\% w przypadku PSL do 41\% na listach Koalicji Obywatelskiej. Podobnie jak w przypadku wyborów do PE rozkład kandydatów naukowców na listach poszczególnych komitetów ukazuje tabela 2. Pokazuje ona, że w przypadku trzech komitetów wyborczych (PiS, SLD, Koalicja Obywatelska) udział naukowców w zarejestrowanych listach jest zbliżony i mieści się w założonym w hipotezie nr 1 odchyleniu. Jest on natomiast zauważalnie mniejszy w przypadku PSL i szczególnie Konfederacji, na listach, której naukowcy stanowili mniej niż 1\% ogółu kandydatów.

W przeciwieństwie do wyborów europejskich w elekcji sejmowej daje się także zauważyć zróżnicowanie w zakresie obecności reprezentantów poszczególnych dziedzin nauki na zarejestrowanych listach. W przypadku kandydatów z grona badaczy nauk społecznych i humanistycznych jest dostrzegalna ich nieco większa reprezentacja na listach SLD i Koalicji Obywatelskiej, niższa natomiast na listach PiS, PSL i Konfederacji. Z odwrotną sytuacją, zgodną z założeniem zawartym w hipotezie nr 3, mamy natomiast do czynienia w przypadku reprezentantów nauk ścisłych, technicznych i rolnych, którzy w największym stopniu obecni byli na listach Konfederacji, PSL i PiS, nieco w mniejszym stopniu Koalicji Obywatelskiej i w zdecydowanie najmniejszym stopniu na listach SLD.

Na zakończenie analizy przytoczę dane dotyczące kandydatów do Senatu, choć przypomnę, że ze względu na polityczne porozumienie, jakie zawarły przed tą elekcją trzy spośród pięciu badanych komitetów, 
Tabela 2. Udział naukowców na listach wyborczych w wyborach do Sejmu

\begin{tabular}{|c|c|c|c|c|c|}
\hline Dziedzina nauki /KW & PSL & PiS & SLD & Konfederacja & $\begin{array}{c}\text { Koalicja } \\
\text { Obywatelska }\end{array}$ \\
\hline Humanistyczne (\%) & $6(31,6)$ & $6(23)$ & $12(36,4)$ & - & $6(20,6)$ \\
\hline Inżynieryjne i techniczne (\%) & $2(10,6)$ & $4(15,4)$ & $2(6)$ & - & $3(10,3)$ \\
\hline Medyczne i nauki o zdrowiu (\%) & $2(10,6)$ & $1(3,9)$ & $1(3)$ & $1(16,6)$ & - \\
\hline Rolne i Leśne (\%) & - & - & - & $1(16,6)$ & - \\
\hline Społeczne (\%) & $5(26)$ & $12(46)$ & $17(51,6)$ & $3(50)$ & $17(58,8)$ \\
\hline Ścisłe i przyrodnicze (\%) & $3(15,9)$ & $2(7,8)$ & $1(3)$ & $1(16,6)$ & $3(10,3)$ \\
\hline Sztuka (\%) & $1(5,3)$ & $1(3,9)$ & - & - & - \\
\hline Teologiczne (\%) & - & - & - & - & - \\
\hline Razem (odsetek ogólnej liczby kandydatów KW) & $19(2 \%)$ & $26(3,1 \%)$ & $33(3,6 \%)$ & $6(0,7 \%)$ & $29(3,1 \%)$ \\
\hline $\begin{array}{l}\text { Mandaty zdobyte przez naukowców (odsetek ogólnej } \\
\text { liczby mandatów KW) }\end{array}$ & $3(10 \%)$ & $8(3,4 \%)$ & $5(10,2 \%)$ & 0 & $9(6,7 \%)$ \\
\hline
\end{tabular}


traktujęje, jako informację uzupełniającą. W wyborach do Senatu wystartowało łącznie 279 kandydatów, w tym 25 naukowców (9\%). W tym gronie były 4 kobiety (16\%) i 21 mężczyzn (84\%). Najwięcej kandydatów do Senatu spośród naukowców zarejestrował PiS (14) oraz Koalicja Obywatelska (7), pozostali kandydaci reprezentowali SLD (1) oraz inne niebędące przedmiotem zainteresowania autora komitety (3). Interesującą odmiennością elekcji senackiej od elekcji sejmowej i wyborów europejskich był rozkład kandydatów reprezentujących poszczególne dziedziny. 0 ile bowiem największą grupę wśród 25 kandydatów stanowili reprezentanci nauk społecznych (40\%), o tyle za nimi uplasowali się przedstawiciele nauk ścisłych i przyrodniczych (24\%) oraz technicznych (16\%).

\section{Wnioski}

Podsumowując, na wstępie skoncentruję się na weryfikacji hipotez. Analiza list kandydatów zarejestrowanych w badanych elekcjach pozwala stwierdzić, że założone hipotezy zostały pozytywnie zweryfikowane tylko częściowo, jednak, co warte podkreślenia, znalazły one potwierdzenie w odniesieniu do elekcji sejmowej w przeciwieństwie do wyborów do Parlamentu Europejskiego i Senatu. Sądzę więc, że specyfika tych dwóch ostatnich elekcji, w których komitety wyborcze koncentrują się na promocji kandydatów, posiadających określone cechy wizerunkowe, jak np. wykształcenie, wiek, znajomość języków obcych, a być może nawet szerzej „znajomość świata” powoduje, że chętniej sięgają one po naukowców i dlatego brak jest znaczących różnic w wymiarze ilościowej aktywności naukowców w tych wyborach. Natomiast w przypadku elekcji sejmowej mamy w pewnym sensie do czynienia ze zjawiskiem wpisywania się obecności naukowców na listach w podziały społeczne i polityczne determinujące przebieg wyborczej rywalizacji. W tym kontekście interesujący może być fakt, że naukowcy stanowili 2,5\% ogółu kandydatów w badanych komitetach wyborczych, czyli praktycznie tyle samo, ile w 2018 roku w ogólnej liczbie zatrudnionych było pracowników sektora badań i rozwoju, z czego nieco ponad połowa pracowała w szkolnictwie wyższym. ${ }^{22}$ Jeśli chodzi natomiast o obecność na listach kandydatów reprezentujących różne dziedziny nauki, to brak wyraźnego zróżnicowania list wyborczych pod tym kątem w konfrontacji z wynikami

22 Mały Rocznik Statystyczny Polski2019, Warszawa 2019, s. 125; Działalność badawcza irozwojowa w Polsce w 2018 r., Szczecin 2019, s. 16. 
badań M. Misiaka i Ł. Sakowskiego należy jak sądzę tłumaczyć złożonością podziałów politycznych w Polsce i ich polaryzacją oraz faktem, że proces identyfikacji z określoną formacją polityczną przez kandydata jest wielowymiarowy.

Jednak dalsza analiza badanych list pozwala dojść do jeszcze kilku wniosków, które w sposób syntetyczny zaprezentowane zostały w tabeli 3.

Tabela 3. Udział naukowców w wyborach w 2019 r z podziałem na dziedziny

\begin{tabular}{|l|c|c|c|c|}
\hline \multicolumn{1}{|c|}{ Dziedzina nauki/Elekcja } & PE & Sejm & Senat & Razem \\
\hline Humanistyczne (\%) & $19(35,8)$ & $30(26,5)$ & $2(8)$ & $51(27)$ \\
\hline Inżynieryjne i techniczne (\%) & $3(5,7)$ & $11(9,7)$ & $4(16)$ & $18(9,5)$ \\
\hline Medyczne i nauki o zdrowiu (\%) & $1(1,9)$ & $5(4,4)$ & $2(8)$ & $8(4)$ \\
\hline Rolne i Leśne (\%) & 0 & $1(0,9)$ & $1(4)$ & $2(1)$ \\
\hline Społeczne (\%) & $26(49)$ & $54(47,8)$ & $10(40)$ & $90(47,5)$ \\
\hline Ścisłe i przyrodnicze (\%) & $4(7,6)$ & $10(8,9)$ & $6(24)$ & $20(10)$ \\
\hline Sztuka (\%) & 0 & $2(1,8)$ & 0 & $2(1)$ \\
\hline Teologiczne (\%) & 0 & 0 & 0 & 0 \\
\hline Razem & $53(6,8 \%)$ & $113(2,5 \%)$ & $25(9 \%)$ & 189 \\
\hline $\begin{array}{l}\text { Mandaty zdobyte przez naukowców } \\
\text { (odsetek ogólnej liczby obsadzonych } \\
\text { w elekcji mandatów) }\end{array}$ & $13(25,5 \%)$ & $25(5,4 \%)$ & $9(9 \%)$ & 47 \\
\hline
\end{tabular}

Źródło: opracowanie własne na podstawie danych z https://pkw.gov.pl (24.01.2020).

Jej lektura pokazuje nam wyraźne dysproporcje, jeśli chodzi o polityczną aktywność reprezentantów poszczególnych dziedzin. Przede wszystkim w grupie naukowców-kandydatów mamy do czynienia ze zdecydowaną przewagą badaczy reprezentujących nauki społeczne i humanistyczne. Takistan rzeczy można przede wszystkim uzasadnić pozostawaniem sfery władzy i rządzenia w obszarze ich naukowych zainteresowań, ale także przydatnością posiadanych przez nich wiedzy i umiejętności (prawnicy, ekonomiści, politolodzy, socjolodzy, psycholodzy, historycy) w polityce. Na końcu wreszcie odniosę się do kwestii wyborczej efektywności kandydatów-naukowców. Jak pokazuje tabela 3, generalnie jest ona wysoka, bowiem w przypadku wyborów do Parlamentu Europejskiego, naukowcy stanowią ponad 25\% wybranych, Senatu 9\%, a Sejmu 5,4\%, należy jednak pamiętać, że w tym ostatnim przypadku stanowili oni dwukrotnie mniejszy odsetek kandydatów. 


\section{Bibliografia}

R. Alberski, Wybrane czynniki wpływające na decyzje wyborców w elekcji parlamentarnej w 2011 roku, «Preferencje polityczne» 2012, nr 3.

I. Boyd, Scientists and politics?, «Science» 2019, vol. 366, issue 6463.

M. Cichosz, (Auto)kreacja wizerunku polityka na przykładzie wyborów prezydenckich w III RP, Toruń 2003.

A. Dziedziczak-Foltyn, Nauczyciele akademiccy jako prekursorzy i moderatorzy społeczeństwa wiedzy, «Nauka i Szkolnictwo Wyższe» 2006, nr 2/28.

T.Gundersen, Scientists as experts: A distinct role, «Studies in History and Philosophy of Science» 2018, nr 69.

H. Hall, Scientists and Politicians, «Bulletin of Atomic Scientists» 1956, vol. 12, nr 2.

M. Mazur, Polityka z twarza. Personalizacja parlamentarnych kampanii wyborczych w Polsce w latach 1993-2011, Katowice 2014.

K. Skarżyńska, Człowiek a polityka. Zarys psychologii politycznej, Warszawa 2005.

D. Skrzypiński, Proces mianowaniakandydatów w wyborach prezydenckich jakomechanizm rozstrzygania dylematów strategicznych, «Studia Politologiczne» 2011, vol. 19.

K. Zajdowski, Marketing produktu politycznego. Analiza porównawcza, Warszawa 2017.

F. Znaniecki, Społeczne role uczonych, Warszawa 1984.

A. Żukiewicz, Społeczny ethos uczonych a procesy „zurzędniczania” nauki, «Rocznik Lubuski» 2018, t. 44, cz. 2. 